\title{
COMBINED EFFECTS OF CULTURAL-LINGUISTIC PROXIMITY AND NATURALIZATION ON POLITICAL INTEGRATION OF FIRST-GENERATION IMMIGRANTS 1
}

\section{EFECTOS COMBINADOS DE LA PROXIMIDAD LINGÜÍSTICO-CULTURAL Y DE LA NATURALIZACIÓN EN LA INTEGRACIÓN POLÍTICA DE INMIGRANTES DE PRIMERA GENERACIÓN}

Josep Lobera*, Santiago Pérez-Nievas ${ }^{\star \star}$ y José Rama**

Abstract: Although the under-participation of ethnic minorities in the electoral field is frequently observed, the nuances of their political engagement remain relatively unexplored by scholars. Particularly, little empirical analysis has attempted to identify the barriers faced by first-generation immigrants to adopt a party preference in their host country. Drawing on a unique survey data with a large sample of first-generation immigrants $(N=2,648)$ in a new migration country (Spain), this article explores the relevance of different set of factors (cultural proximity vs immigration status)

1 A previous version of this paper was presented at the ECPR General Conference 2020 in the panel "New dynamics of immigrants' political engagement". We are very grateful to Daniela Vintila and Angeliki Konstantinidou for their comments that were extremely helpful to improve the paper. We are also thankful to the project “¿Ayuntamientos plurales? La representación política de los inmigrantes en España” (CSO2016-79540-R), funded by the Spanish Ministry of Economy, for financing this activity.

* Universidad Autónoma de Madrid, Department of Sociology.

** Universidad Autónoma de Madrid, Department of Political Science. 
in explaining the acquisition of a party preference among this minority population. We find that cultural proximity (as defined by the country of origin: Latin-American vs the rest) is a strong predictor for the acquisition of a party preference. Additionally, our results suggest that the predictive strength of this factor is reinforced through a naturalization regime that facilitates full political rights to culturally closer immigrants, thus reinforcing their a priori better conditions for political integration. Finally, the results also suggest that permissive (rather than restrictive) naturalization policies might work better to secure the political integration of migrant minorities.

Key words: acquisition of party preference; immigrants; cultural proximity; immigration status; naturalization.

Resumen: Aunque la baja participación de las minorías inmigrantes en el campo electoral es algo que se observa con frecuencia, las razones que están detrás de su vinculación con lo político están relativamente poco exploradas por los académicos. En especial, son pocos los estudios empíricos que hayan buscado identificar las barreras con las que los inmigrantes de primera generación se encuentran para desarrollar una preferencia partidista en su país de acogida. Gracias a los datos de una escueta única con un amplio número de casos de inmigrantes de primera generación $(\mathrm{N}=2.648)$ en un nuevo país de acogida (España), este trabajo explora la relevancia de dos tipos de factores (proximidad cultural vs estatus de inmigración) para entender la adquisición de preferencia partidista en esta población minoritaria. Encontramos que la proximidad cultural (definida por el país de origen: Latinoamericanos vs el resto) es un fuerte predictor para entender la adquisición de identificación partidista. Más aún, nuestros resultados sugieren que la capacidad explicativa de este factor se ve reforzada a través de un régimen de naturalización del inmigrante que facilita la adquisición completa de derechos políticos a aquellos inmigrantes culturalmente cercanos, lo que, a su vez, refuerza las condiciones para una mejor integración política. Finalmente, los resultados muestran que políticas de naturalización permisivas (versus aquellas restrictivas) ayudan a la integración politica de las minorías inmigrantes.

Palabras clave: adquisición de preferencias partidistas; inmigrantes; proximidad cultural; estatus de inmigración; naturalización. 


\section{INTRODUCTION}

Immigrant populations encounter several barriers to participation in their host country's political system. The latest Migrant Integration Policy Index (MIPEX) warns that a large part of the foreign population does not have the right to vote, that immigrants lack representation, and that policies for implementing their participation rights often fail (Huddleston et al., 2015). Across countries, immigrants have played an increasingly important role as they claim greater political rights and visibility.

However, political participation does not occur spontaneously. In order to orient themselves within the larger political system, individuals tend to acquire a party preference. As several scholars have shown, expressing a preference for a political party is a key predictor of political participation among the general population (Dalton and Wattenberg, 2002), as well as among ethnic minorities composed primarily of immigrants (Kam and Ortiz, 1998; Uhlaner \& Garcia, 2005).

Thus, the acquisition of a party preference among migrants can be considered an initial but central step towards understanding the patterns of political integration of immigrant minorities. This issue has been particularly studied in countries with histories of migration (Wong, 2000), but it has been overlooked so far in new immigration contexts. Since political integration has an essential, dynamic character across generations, an analysis of the factors that facilitate or hamper the acquisition of a party preference among the foreign-born population - first-generation immigrants - should shed light on the early stages of this process. In this article we take the acquisition of a party preference as a proxy or indicator of the specific barriers and challenges that migrants face in the process of getting acquainted with a new political system. We assume that our dependent variable is a good measure of political integration for immigrants in its institutional dimension, as we capture those who feel attached to $a$ political party together with those that turned out to vote (see the theoretical section below for a detailed operationalization of the dependent variable).

Our study offers the opportunity to test established theories in a new immigration country by studying the acquisition of political preferences among the foreign-born population in Spain. We aim to answer, at least, three set of relevant questions: (1) what 
sociodemographic factors account for the acquisition of a party preference among first-generation migrants? Do these factors work similarly or differently to predict the acquisition of a party preference among first-generation migrants than they do to explain political involvement in the population at large? (2) What is the relevance of cultural-linguistic proximity in the early stages of political integration of migrant minorities? Are migrant minorities who share linguistic or cultural traits with the host society more prone to acquire a party preference than those minorities who are linguistic and culturally further apart? and (3) Can the immigration status of migrant minorities be more relevant than their cultural background to explain their incorporation into a new political system? Or it might be that cultural factors and immigration status reinforce one another? What is the role of naturalization and/or European citizenship in the political incorporation of migrant minorities?

To answer these questions, we structure the article as follows. In the next section, we contextualize the Spanish case, describing briefly the main migration flows to Spain over the last two decades and paying particular attention to their differences in cultural background, immigration status, and voting rights. In the second section we present the literature review, and we formulate our main hypothesis. In the third section, we discuss the data, the operationalization of the variables, and the models presented to answer our questions. In the final section, we present the results and comment on our main findings.

\section{THE SPANISH CONTEXT: DIFFERENCES IN THE IMMIGRATION STATUS AND THE CULTURAL-LINGUISTIC PROFILE OF IMMIGRANT MINORITIES IN SPAIN}

The Spanish case is analytically useful to shed light on mechanism of the impact of cultural/linguistic proximity and immigration status on political integration for a number of reasons. First, it is only relatively recent that the country has become an immigrationreceiving country. It also stands out as one of the EU Member States that witnessed the most rapid and accelerated intake of migrants. Such inflows intensified especially since the beginning of the 2000s to the extent that the stock of foreign-born residents increased, from $3 \%$ of the total population in the late 1990 s to $14 \%$ in 2019 (Figure 1). 
By 2017, the number of foreign-born residents was exceeding the 6.7 million, making Spain one of the main European destinations for both intra-EU and non-EU migrants.

FIGURE 1

EVOLUTION OF THE STOCKS OF FOREIGN-BORN RESIDENTS IN SPAIN, 1998-2019. TOTAL NUMBERS AND SHARES OVER THE TOTAL POPULATION

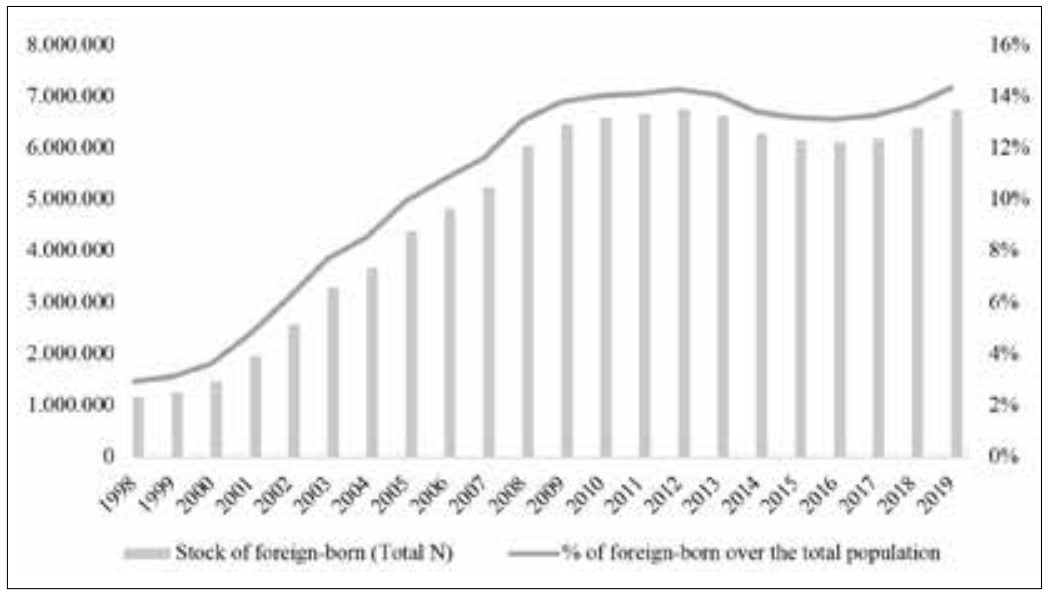

Source: own elaboration with the data of the Spanish National Institute for Statistics (INE), several years.

Secondly, the migrant population in Spain is highly diverse in terms of the national origin of its migration flows. Until mid-1990s, there was a predominance of European immigration, fewer inflows from Africa (mostly Morocco), and quite limited arrivals from Latin American (Cebolla Boado \& González Ferrer, 2008). Since the early 2000s, immigration from Africa intensified, particularly with new arrivals of labour migrants from Morocco, whereas the stocks of Latin Americans diversified, with language closeness and postcolonial ties favouring inflows of Ecuadorians, Colombians, Peruvians and Bolivians in search for job opportunities. From the mid to late 2000s, there was a new arrival of European migrants. Within this group, we can generally distinguish inflows originating from Western Europe (especially Germany, the UK and France), driven primarily by lifestyle migration and highly qualified jobs 
(Rodríguez et al., 2010; Janoschka, 2011) from those originating in new EU member-states (particularly Romania and Bulgaria) more frequently driven by labour-market opportunities of the fast-growing Spanish economy before 2008.

Figure 2 shows the distribution of the most sizeable groups of foreign-born residents in Spain in 2017, i.e. the year of the survey data that we analyse below. Latin Americans were then the largest migrant community (38\% of all foreign-born residents), with most of them coming from Ecuador (6.5\%), Colombia (6\%), Argentina (4.1\%), Venezuela (3.4\%), Peru (3.1\%), Bolivia (2.7\%), or the Dominican Republic (2.7\%). Migrants from the EU28 countries accounted for $29.1 \%$, with the most sizeable communities originating from Romania (9.9\%), the UK (4\%), France (3.3\%), and Germany $(2.7 \%)$. Other than that, Moroccans (13\%) were the largest group by national origin, well ahead of China (3.1\%) the next largest nonLatin American non-EU group.

FigURE 2

FOREIGN-BORN POPULATION IN SPAIN, BY ORIGINS (MOST SIZEABLE GROUPS) IN 2017. SHARE OF EACH GROUP FROM THE FOREIGN-BORN POPULATION

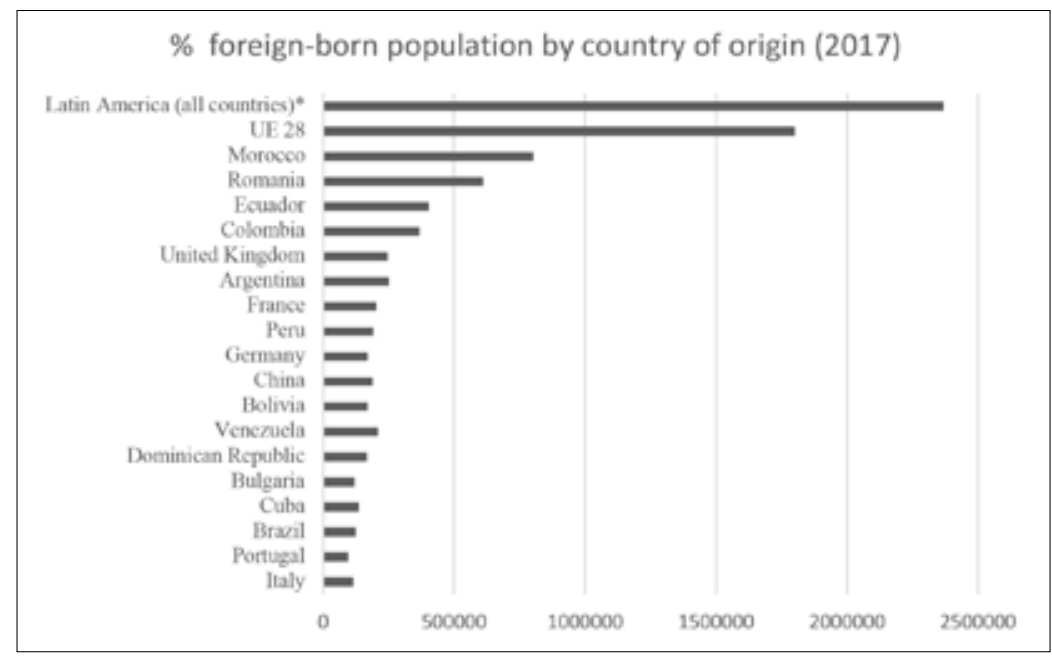

Source: own elaboration with the data of the Spanish National Institute for Statistics (INE), 2017. 
Thirdly, these migrant groups also differ significantly in the citizenship status that each group enjoys and thus the legal pathways of access to Spanish politics (Pérez-Nievas et al., 2014) to the extent we might talk of a certain "hierarchy" between groups according to their national origin. These inequalities between groups in terms of immigration status arise basically from two factors: European citizenship, on the one hand, and the differences in access to naturalization (i.e., the take-up of Spanish citizenship) applied to different nationalities of origin.

As European citizens, the nationalities from the EU enjoy full access to residence rights and the labour market. Additionally, EU citizens enjoy the right to vote and stand as candidates in both Spanish local elections and European Elections, upon arrival to the country. Nonetheless, it must be noted that EU migrants face higher administrative barriers before they can exercise their voting rights at the local or European level: whereas Spanish citizens are registered automatically from the information provided by the local administrative census (Padrón), European citizens are required to register on the electoral roll the first time they vote in a local election. There are other national minorities that have voting rights "on paper" but with little effects "in practice".

After a number of reciprocity agreements signed by the Spanish State in 2011, immigrant residents from ten other non-EU nationalities (some of them Latin American) can access - at least formally - the right to active "suffrage" in local elections, provided they meet certain criteria which are, however, much stricter for them than for EU citizens: in order to be entitled to vote they need to have resided in Spain "legally" for at least five years, and those finally entitled have to register on the electoral roll for every local election. As a result -also from the lack of institutional campaigns to inform about these rights - the impact of these bilateral agreements on the actual voting rights of the foreign population in Spain has been negligible, particularly if we compare it to that of European citizenship ${ }^{2}$.

2 The 2011 bilateral agreements involved Bolivia, Cape Green, Colombia, Chile, Ecuador, Iceland, New Zealand, Norway (1990), Paraguay and Peru, thus including some of the most relevant immigrant Latin American nationalities in Spain. In the previous local election (2015) to our survey data, only 21,609 Latin Americans were registered to vote via these bilateral agreements, by contrast to the 450.000 European Citizens registered to vote in those same elections (Data from the National Statistics Institute, INE, Electoral Census of Foreign 
However, even if migrant minorities of EU origin enjoy a privileged immigration status in the short term, those from LatinAmericans also have their own advantages that arise from their preferential access to naturalization. Whereas the standard ordinary naturalization process requires a qualifying period of ten years of prior legal residence, nationalities that share past colonial ties with Spain - which includes all Latin American countries ${ }^{3}$ - benefit from a fast track access after only two years of residence and they are also allowed to keep double nationality. Such institutional arrangement clearly places Latin Americans in a better position than other groups to access Spanish nationality, which is demonstrated by the fact that, of the 1,291,379 migrants naturalised in Spain in the period 1996$2015,76 \%$ of them were Latin-Americans, followed by Moroccans (15\%), whereas only $2 \%$ were from EU nationalities.

In short, these differences in access to political rights generate a diverse political opportunity structure for participation, creating different incentives structures for migrants to get involved in the politics of the host country. Nevertheless, following the abovementioned idea of a hierarchy of migrant groups in terms of political rights, it is not self-evident what group - whether EU nationalities or those from Latin-America- should be placed first at the top. On the one hand, EU immigrants clearly enjoy an advantage in the short term, given their access to residential and political rights (at the local level) upon arrival. However, EU immigrants have few incentives to naturalize and they face higher barriers than Latin Americans to do so. On the other hand, Latin American immigrants have a less favourable immigration status than EU citizens upon arrival -like the rest of third country nationals-, but they have a privileged access to naturalization - demonstrated by the fact that they do indeed naturalize at much higher rates than other groups. At the bottom of the political rights' hierarchy, we find those migrants who are neither European citizens, nor do they have a privileged access to

Residents, CERE for the local elections of 2011 and 2015. Available at https:// www.ine.es, last accessed 17/01/2021) Hence we argue that the impact in voting rights for immigrants from these bilateral agreements has been negligible and discard it in our theoretical framework as a relevant incentive for political engagement.

3 Citizens from Guinea Equatorial and the Philippines (as former Spanish colonies) also benefit from this fast track naturalization but the size of migrant minorities from these two nationalities are numerically irrelevant. 
naturalization: a heterogeneous group that includes North Africans, Sub-Saharan Africans and Asian minorities. In the next two sections we theorize how these differences in immigration status might have an impact (separately or combined with cultural characteristics) to produce different outcomes in the political incorporation of different minorities (as measured by the acquisition of a party preference).

\section{THEORETICAL FRAMEWORK}

In this article we are not interested in the acquisition of party preference as a predictor of electoral turnout or vote choice, but as a proxy or indicator of the specific barriers and challenges that migrants face in the process of getting acquainted with a new and different political system (given that they are first-generation immigrants), i.e. the political system of their host society. In this respect our dependent variable can be possibly best related to the more general concept of political engagement, yet with the particular connotation that we analyse the political engagement of first-generation migrants in their process of getting acquainted with a political system that is new to them. This is why we define and operationalize our dependent variable as a compound variable to identify those migrants who are able to choose $a$ party (any party), either because they voted for it (for that minority in our migrants' sample who are citizens and have the right to vote), or because they expressed sympathy for it; and distinguish them from those migrants who did not vote, nor did they declare sympathy for any party.

Keeping in mind that we analyse a form of political engagement for a quite specific population subgroup (first-generation migrants) we start this theoretical section from the assumption that some of the factors that determine the political engagement of this subgroup might be different - and unique to the migration experiencefrom the factors that determine the political engagement of the population at large (see De Roiij's, 2012, p. 457). In fact, our two main independent variables - cultural proximity and immigration status - clearly belong to the category of "different" factors, directly connected to the specific conditions of first-generation migrants, which cannot be applied to the rest of the population. Nonetheless, the political engagement of migrants can also be influenced by many 
of the same individual factors (gender, age, education, etc.) that have an effect on the political engagement of the population at large, even if these individual factors work differently (or not) for their specific subgroup (De Roiij's, 2012, p. 457).

Following the aforementioned distinction, in this section we revise the factors that might have an impact on the probability of migrants to acquire a preference with a political party. We start with a subsection about the effects of sociodemographic factors. We then move to examine how cultural proximity (as defined by country of origin) can influence the political engagement of migrants considering the specificities of the Spanish context. Finally, we theorize about the effects of immigration status, while also specifically revising how the Spanish naturalization regime can affect the political engagement of migrants. This final subsection explores whether cultural proximity and immigration status can operate combined or separately, to influence the political engagement of immigrant minorities.

\subsection{Sociodemographic Factors}

Political behaviour has been traditionally explained as a genderdifferentiated phenomena. These differences may derive from dissimilar socialization processes that can consequently influence access to political knowledge and political engagement (Fraile, 2014). Whereas some previous studies have found that males tend to be more interested in, attentive to, and knowledgeable about politics (Bennett and Bennett, 1989) other studies however show that females are more likely to report a partisan identification than males (Campbell, 1960). Thus, we include gender as a control variable in our analysis below with no particular expectation.

However, we have more clear expectations with regard to the effect of education on the political engagement of migrants. Classical works on political behaviour have universally established that education reduces the costs of voting by equipping people with the skills that are needed to gain political knowledge and efficacy (Gallego, 2010). Additionally, the level of education often shows the greatest impact on the likelihood of political participation (Adamson, 2007). Therefore, we expect higher levels of educational attainment to have a positive effect on the capability of migrants to acquire a party preference. 
With regard to age we derive some contradictory expectations from previous literature. On the one hand, it is well-known from traditional studies of political engagement that young people hold less clear political preferences and show weaker party identification than older people (Dassonneville, 2013, p. 43), even if they might be more open to other non-institutional forms of participation. In the case of migrants, however, the effect of age might be intermediated by two factors that are specific to the migrant experience: length of stay, on the one hand, and the age of migrants at the time of arrival. Duration of stay in the host country obviously matters, by shaping migrants' familiarity with the new political system (Morales \& Giugni, 2011; Schönwälder, 2013). But time of residence can also interact with different age groups, in the case of migrants, to upturn the positive effect that classical studies attribute to age on institutional political engagement. In this respect, Portes et al. (2012) identified age as a retarding factor of adaptation among foreign-born migrants (see also Morales, 2011). Delving deeper into this line of reasoning, older age might be negatively associated with the acquisition of a party preference, particularly for those individuals who arrived to the host society as adults, or after a certain age threshold, which makes them less malleable to the influence of socialization processes. Although time affects acculturation, younger generations of immigrants might be more easily affected by this process in the host country than older ones. Thus, we include both length of stay and age at the time of arrival to the host country as control variables, expecting a positive effect in the first case, and a negative effect in the second.

\subsection{Cultural and Linguistic Proximity}

Having the language of the host society as native tongue can act as a key factor in political integration, particularly in its early phases, and even more so in new migration countries where most members of ethnic minorities are first-generation residents, as it is the case of Spain. Knowledge of the language of the host society can play an essential role to acquire social capital (Heizmann \& Boehnke, 2016) as well as feeling of belonging to the host country (Lobera, 2021), and it is an essential skill for political participation (Barreto \& Muñoz, 2003; Morales, 2011; Morales \& Giugni, 2011; Cinalli \& Giugni, 2011). More importantly, language barriers impose high 
information costs to non-native speakers (Hawthorne, 2005; Soto \& Merolla, 2006), and can act as important constraints on access to political information (Wong, 2000), a crucial aspect for getting aquatinted with the political system of the host country, and more specifically with its party system. More generally, language skills in the (predominant) language of the host country can be central to the initial adaptation of immigrants (Calvo Buezas, 2019, p. 107). Low levels of proficiency in the language of the host society by immigrants can result in a lower ability to access social services, downward assimilation, failure to naturalize, and restriction to co-ethnic enclaves (Portes et al., 2009; Duncan \& Waldorf, 2009; McAreavey, 2017; Gustafson \& Cardozo, 2017).

Given the advantages that having the predominant language of the host society as mother tongue can provide, particularly in the initial phases after arrival, it is not surprising the pulling effect that the fast-expanding Spanish economy of the 2000's had on a number of Latin-American nationalities, to which Spain offered linguistic and cultural proximity and thus (potentially) lower cost of integration (Connor \& Massey, 2010; Joppke, 2005; Pamies et al., 2021). Although Latin-American immigrants may still face discrimination based on their accent, or other difficulties (particularly in Spanish regions with co-official regional languages), the advantage that Spanish as predominant language provides to Latin-Americans in relation to other migrant minorities cannot be overrated.

In this sense the country of origin of migrant minorities (LatinAmerican origin versus the rest) possibly transcends the mere linguistic proximity and also captures a cultural dimension that creates a more favourable context of reception for Latin-Americans. This more favourable environment for their integration (also in the political sphere) can be seen in different domains. For instance, although levels of hostility towards immigrants are generally lower in Spain than in other European countries (Heath and Richards 2019), surveys measuring attitudes towards immigrants consistently find that Latin Americans attract the most positive attitudes, more positive than those towards other Western European nationalities (Lasala-Blanco et al., 2021). This more favourable context of reception works in addition to the greater resources enjoyed by Latin-American migrants from having Spanish as their first language. Considering all the above, in our data analysis below we expect to find a positive effect of having a Latin-American origin 
on the political engagement of immigrants (as measured as by the acquisition of a party preference).

\subsection{Immigration Status}

Nevertheless, length of stay or cultural proximity to the host country might not be enough if migrants find themselves in a vulnerable legal status, and/or if they lack formal opportunities or incentives for getting politically involved. In this respect, immigration status can play a relevant role for two different reasons. Legal status is directly connected to migrants' rights in a number of important domains (family reunification, access to legal employment, security of residence permit, etc.) and, therefore, a more permanent legal status reduces the risk of social exclusion, thus affecting the integration of migrants in a very relevant, albeit more general, sense (González Ferrer, 2011). Additionally, previous research shows that securing stronger legal status to guarantee those rights is in fact one of the main drivers for migrants to apply for naturalization (Nam \& Kim, 2012).

A second reason for their relevance is because citizenship statutes can directly shape the opportunities and incentives for migrants to get involved in the politics of the host country. These opportunities/ incentives, in turn, are dependent on existing institutional rules that operate in the host country which can be more or less permissive of minorities' inclusion (Donovan, 2007) by creating varying structures of political opportunities for different migrant groups. Distinctive regulations for accessing voting rights selectively applied for different foreign groups might have an impact in their political engagement. Immigrants having the right to vote in all or, at least, some elections, will have a stronger incentive to acquire a party preference. Similarly, the host country's regulations on citizenship status - with naturalization leading to full recognition of political rights - might also explain why some groups are in a better position to get involved (Koopmans et al., 2005; Donovan, 2007), particularly if they differ significantly depending on characteristics of the applicant, as it is the case in Spain.

In this vein, Spain is a particularly interesting case for its multiplicity of rules and therefore the high variation in the legal status found for different migrant minorities. This internal variation 
is due to the combined effects of two factors: 1) EU citizenship and the existence of important contingents of EU citizens found among its most relevant immigrant minorities (including labour migration flows such as those from Eastern Europe); 2) the sui-generis character of the Spanish regulations to access full political rights, which following a comparative perspective, is quite atypical for what nowadays stands as a full-fledged western immigration receiving society. We now examine how these two factors can impinge on the political engagement of different migrant minorities.

\subsubsection{European Citizenship}

Following a perspective that considers the issue of immigrant status alone -i.e. leaving any arguments of cultural proximity aside- EU citizens clearly enjoy an advantage over all other migrant minorities for their political integration, at least in short term. On the one hand, minorities from the EU countries enjoy a status, upon arrival to the country, that gives them access to a majority of rights that are linked to residential status (family reunification, free of movement, see Groeber, 2016) whereas all remaining migrant minorities - third country nationals - need at least some passing of time to ascend the steps (from temporary to permanent residency, leading eventually to naturalization) that allows them to secure fully those same rights. On the other, European citizenship also gives them access to voting rights in local and European elections - even if in exercising these rights they face higher administrative barriers than Spanish citizens-. Thus, following formal rules, EU citizens would have more institutional incentives to be politically involved than any other minority, even if full political rights — voting rights at the regional and national levels- are restricted to them (as they are restricted for the remaining minorities unless they naturalize).

However, these advantageous access of EU citizens to social/ residential rights, can also - in the medium/long term - produce unintended and paradoxical result with regard to their political integration in relation to that of other minorities. Since residential/ social rights are guaranteed for EU immigrants in any case, individuals from these nationalities might end having less incentives than other minorities to apply for naturalization (Joppke, 2010; Groeber, 2016). Given that only full citizenship gives access to full voting rights, if EU citizens apply and they access naturalization 
at lower rates than other minorities, they can end up facing lesser institutional incentives to become politically engaged.

\subsubsection{Naturalization}

In general, immigrants face different barriers to naturalization depending on their origin, even in host countries trying to implement meritocratic policies (Rissing \& Castilla, 2014). Additionally, there is a different propensity for naturalization depending on certain individual characteristics and country of origin. Thus, for example, the literature shows that immigrants from countries with lower development rates are more likely to apply for naturalization (Vink et al., 2013).

Naturalization helps immigrants to have greater security in their residence status and gives them greater economic, social and political rights. In this vein, the literature shows positive effects of naturalization in various areas of social integration, from better health conditions to greater political integration (Hainmueller et al., 2015), through greater social and economic integration (Bloemraad, 2017; Peters et al., 2019). Additionally, other works have argued that this positive effect might be mediated by the different barriers to naturalization faced by several immigrant groups - and not just naturalization per se- since the process can often take several years; it compels migrants to interact with the administration of the country, and often it requests from them to acquire knowledge about the politics of the host country (DeSippio, 1996; Wong, 2000; Gonzalez Ferrer, 2011, p. 64) ${ }^{4}$.

While there is some consensus in the literature that naturalization fosters political integration, there is still some controversy on how far these effects go, as well as about the mechanism through which they operate (Morales \& Giugni, 2011, p. 22; Hainmüller et al. 2015, p. 12651; González Ferrer, 2011, p. 67). Among these controversies, the issue of how the design of a naturalization policy will affect the integration of migrants stands out (Hainmüller et al. 2015, p. 12651). Advocates for a more permissive naturalization policy usually argue that it will contribute to accelerate and strengthen the integration

4 In Spain the standardized procedure for naturalization includes a test on knowledge about Spanish society as well as on the Spanish Constitution (Huddleston \& Daj Tjaden, 2012). 
of the immigrants (Haimüller et al. 2015, p. 2015; González Ferrer, 2011, pp. 67-8). Advocates of more restrictive naturalization policy, on the contrary, conceive naturalization as a reward that "culminates" a previous integration process, what has been called as the selection hypothesis: "the tougher the naturalization rules, the more selective the process and thus the more similar new and old citizens will be"; and the other way around, political engagement might be lower where the access to naturalization is not demanding enough (González Ferrer, 2011, pp. 67-8).

In this respect, the Spanish set of regulations for the naturalization of foreigners allows to tentatively test the selection hypothesis since it embodies simultaneously within a single policy two models: a permissive model as well as a restrictive one, depending on the target minority group. For those who have a permanent residency, the Spanish naturalization regime sets two tracks ${ }^{5}$ : an ordinary path - designed for third country nationals (TCNs) who are not from Latin-American countries and the few European citizens who choose to naturalize - requires 10 years of previous residence and the renunciation of the previous nationality which are quite restrictive requirements in European comparative terms; and, a second far more permissive one for countries with prior colonial bonds with Spain -i.e, mostly Latin American nationalities - which envisages only 2 years of previous residency while it also allows to keep dual nationality (Finotelli \& La Barbera, 2013, p. 250). The aggregate combined effect of these two models places Spain slightly above the European average, but this is the results of the much higher naturalization rates among Latin Americans, in such a way that the exceptional path of access has become the more frequent path of naturalization de facto (ibid.).

Thus, we conclude this section with a set of expectations about the effect that naturalization can have for each of our naturalized groups; in relation to the other naturalized group; to non-naturalized groups, and to European citizens. Of course, the two group of variables (cultural proximity and access to citizenship) overlap perfectly, which poses some problems to disentangle its respective

5 Applications from previous permanent residency are the overwhelming majority of applications by first-generation migrants who follow either of the two mentioned paths depending on their nationality of origin (for an overview, see Martinez de Lizarrondo, 2016). 
effects when examining individual data. However, following the selection hypothesis, the two variables should work in opposite directions, so if the selection hypothesis holds the two naturalized groups should come closer in their predictive probability of acquiring a party preference after naturalization, and not move further apart (see next section on methods and analysis). In order to test this, we have divided our sample into 5 groups: 1) non-naturalized European citizens; 2) non-naturalized Latin Americans; 3) naturalized Latin Americans; 4) non-naturalized other TCNs; 5) naturalized other TCNs.

Starting with EU immigrant minorities (group 1), we have argued that their access to residence rights and (limited) political rights possibly gives them an advantage in the short term, but also less incentives to naturalize than any other group. This implies that, as the naturalization process progresses, naturalized groups will leap-frog EU citizens in their access to political rights, potentially resulting in a greater political involvement of these naturalized groups in relation to EU citizens

With regard to the two Latin American groups (2 and 3), we naturally expect group 3 to be more politically engaged given their naturalized status. Also, following the cultural hypothesis, we expect group 2 and 3 to be more politically engaged than their equivalent non-Latin American groups (groups 4 and 5). However, if the selection hypothesis holds, an easier access to naturalization (less selective in time residence requirements and not renouncing the nationality of origin) might draw less motivated applicants to naturalize which could lead to less politically involved (integrated) citizens. Thus, the observed differences in the probability of having a party preference between groups 3 and 5 should be reduced (after naturalization) in relation to the observed differences between groups 2 and 4 (before naturalization), to the extent that a more selective process "compensates" an initial cultural disadvantage.

Finally, we expect that the cultural factor will work to the disadvantage of non-Latino third country nationals (groups 4 and 5). However, it might be that the more restrictive/selective policy facing non-Latin-American third country nationals serves to actually draw more motivated applicants, leading to more politically involved citizens, in which case the observed differences after naturalization should be reduced (as mentioned above). It is nonetheless clear that group 4 (non-naturalized other TCNs) will be the least politically 
involved of all groups. In short, our proposed research design not only allows us to test the political engagement of different migrant minorities but also tentative assess the results of different naturalization policy designs.

\subsection{Data and methods}

In order to answer our research questions, we use data from the 4th Survey on Intercultural Coexistence on the Local Level in Spain 2017 performed by IMEDES-UAM (Giménez et al., 2018). We included questions that allow us to relate partisan identification variables with individual and contextual sociodemographic factors. In this survey, a total of 2,648 personal interviews (face to face) were carried out on foreign-born people who were 18 years of age or older and lived in 26 highly-diverse territories in Spain. 70\% were household interviews, through the generation of random routes, and $30 \%$ street-based interviews, selecting some crowded streets for each area. Gender, origin and age quotas were applied to each territory.

The surveys have been carried out in 25 highly-diverse territories: some of them single municipalities while others are specific districts within larger cities ${ }^{6}$. The general characteristics of superdiversity identified by Vertovec $(2006 ; 2007)$ can be applied to these territories: on average, $29.9 \%$ of the population of their population is foreign-born. Foreign nationalities with the greatest presence are Moroccans (15.3\%), Romanians (10.1\%), Ecuadorians (7.3\%), and Pakistanis $(6.5 \%)$.

In order to test our hypothesis, we create a Dependent Variable (DV) that includes both, the sympathy with a political option and vote recall for those voters able to cast a vote in the June 2016 Spanish general elections ${ }^{7}$. In this sense, the DV was created as follows: we codify with 1 those immigrants who voted in previous elections plus those who did not/cannot vote but expressed sympathy for any political party. We assign the 0 value to those citizens that did not/ could not vote and did not express sympathy for any political party. We have 1,626 cases without party identification because they did

6 For the list of the 25 highly diverse territories see (Giménez et al., 2018).

The survey was not a post-electoral survey, fieldwork was carried out over a year after the June 2016 election. 
not express any sympathy, nor they voted in previous elections; 386 electors that cast a vote for any political option, and 468 individuals who did not vote but expressed sympathy with one party (thus 1,626 cases versus 872 cases) ${ }^{8}$, Given the nature of our DV (a dichotomous variable), logistic regressions were run.

Our models include some control variables of sociodemographic characteristics: gender $(0=$ male; $1=$ female $)$, age $(1=18 / 34 ; 2=35 / 54$; $3=>55)$, and educational level $(0=$ lower than University degree; $1=$ University degree). Additionally, length of stay (measured in number of years). To measure the cultural hypothesis, we create a dummy variable for the migrant's origin ( $1=$ Latin-America; $0=$ other $)$. At the same time, and in order to test the effect of naturalization, we build a dichotomous variable codified as 0 for those non-naturalised and 1 for those naturalized. Finally, and as a combination of both the cultural and immigrant status explanation, we generate a five categorical variable: $1=$ EU citizens (non-naturalized); $2=$ Latin-Americans (nonnaturalized); $3=$ Naturalized Latin-Americans; $4=$ Other TCNs (nonnaturalized); $5=$ Naturalized other TCNs. The distribution of this variable is the following: $19.12 \%$ of EU citizens $(\mathrm{N}=476) ; 23.22 \%$ nonnaturalized Latin-Americans $(\mathrm{N}=578) ; 12.66 \%$ of naturalized LatinAmerican ( $\mathrm{N}=315) ; 38.17 \%$ of non-naturalized other TCNs $(\mathrm{N}=950)$, and $6.83 \%$ of naturalized other TCNs $(\mathrm{N}=170)^{9,10}$.

The three hypotheses are tested separately in different statistical models in order to avoid problems of multicollinearity. Table 1 displays the descriptive of the variables (number of cases, mean, standard deviation, maximum and minimum) and the specific VIFs (variance inflation factors). Regarding this, all variables are well

8 We justify the selection of this DV as a proxy of political integration since it combines two of the most frequent ways to get involved in party politics: turnout and party identification. This methodological option of using a combined DV allowed us to expand the $\mathrm{N}$ of our study and to test robust analysis. The low $\mathrm{N}$ is a frequent problem in immigration studies, particularly so in the research that deals with political involvement where limitations to access to political rights may be implicated.

9 These percentages reflect the higher naturalization rate (3 to 1 ) in our survey among Latin-American migrants than among other TCNs that we know from official statistical data (see section on case study).

10 Yet, there is a $6^{\text {th }}$ group of naturalized citizens originating from EU countries but these were too few in our sample (N: 56) to make a statistically interpretable category of this group, which in any case constitute only $2 \%$ of those who have naturalized, as explained in the case study section. 
below the levels that would rise concerns of collinearity problems (see last column of Table 1): the mean VIF is 1.22 and the maxim one 1.36 (Citizenship).

TABLE 1

DESCRIPTIVES OF INDEPENDENT VARIABLES

\begin{tabular}{|l|c|c|c|c|c|c|}
\hline Variables & Obs & Mean & $\begin{array}{c}\text { Std. } \\
\text { Dev. }\end{array}$ & Min & Max & VIF \\
\hline Gender (1=Female) & 2.498 & 0,50 & 0,50 & 0 & 1 & 1.03 \\
\hline Age (categorical) & 2.498 & 1,83 & 0,71 & 1 & 3 & 1.16 \\
\hline Education (1=University) & 2.490 & 0,17 & 0,38 & 0 & 1 & 1.04 \\
\hline Length of stay in Spain & 2.377 & 13,71 & 8,82 & 0 & 60 & 1.28 \\
\hline Cultural (1=Latin-American) & 2.489 & 0,36 & 0,48 & 0 & 1 & 1.32 \\
\hline Citizenship (1=Naturalised) & 2.491 & 0,22 & 0,41 & 0 & 1 & 1.36 \\
\hline Citizenship \& cultural & 2.489 & 2,90 & 1,28 & 1 & 5 & 1.33 \\
\hline
\end{tabular}

Source: own elaboration based on 4th survey on Intercultural Coexistence on the Local Level in Spain 2017 (Giménez et al., 2018).

\subsection{Results and Discussion}

Table 2 presents four statistical models tounderstand the acquisition of party preference by first-generation immigrants, as proxy of their political integration. Regarding the sociodemographic characteristics, we find that men have a positive effect in all models, in line with the previous literature that establishes that males are more attentive to, and knowledgeable about party politics than females (Bennett and Bennett, 1989). Also, college education promotes political integration, as measured by party identification, in all models, in line with findings by previous studies (Adamson, 2007; Cho, 2009).

With the partial exception of Model 3 (not statistically significant for the 18-34 age category), age seems to have an effect on the acquisition of a party preference. As the category of reference are those older than 54 years, Models 1, 2 and 4 show that those citizens between 18 and 34 as well as those between 35 and 44 years are more likely to acquire a party preference. Thus, age has a distinct effect on the DV and vote among thus corresponding with acculturalization theories (Portes et al., 2012) rather than those applied for the 
general population (Dassonneville, 2013). Length of stay, of course, also matters: those who have lived in Spain for longer show higher probabilities to feel political integrated, as confirmed in Table 2 in all of the models ${ }^{11,12}$.

Moving to our three hypotheses, Model 2 confirms our first hypothesis (cultural approach), confirming that immigrant minorities from Latin-American countries are more prone to acquire a party preference in the host country (even when we control for sociodemographic characteristics and length of stay), than immigrants from other regions (EU and other TCNs). Model 3 tests the effects of naturalization (for all naturalized). In this sense, those naturalized immigrants, i.e. those with the Spanish nationality (compared with those non-naturalised) exhibit a highest probability to acquire a party preference with a Spanish political party ( $\mathrm{p}$ value $<0.01$ ).

Finally, Model 4 displays the results of our final model which tests the combined effects of cultural proximity and immigrant status. We take the group of non-naturalized other TCNs as the reference category because, following our theoretical expectations above, we expect this to be the least politically integrated group. This is indeed confirmed by empirical results that show that all other groups have a significantly positive relationship with the DV in relation to the reference category. However, this positive effect is statistically weaker for EU citizens than for the other three groups (including nonnaturalized Latin Americans). This is an interesting result since it underlines the weak relevance of security of residential status (EU citizens) when compared to cultural proximity (since the positive effect of the non-naturalized Latin American group is more significant). The results also confirm the stronger effect of the two naturalized groups in relation to EU citizens, although this was to be expected.

11 We also replicated the first model but changing length of stay for an alternative variable that measures the age at the time of arrival (the result of subtracting age minus time of residence). Results (not shown) confirms our expectation of a negative and statistically significant (Coef. $=-0.034$; $p$ value $<0.001$ ) relationship. For the remaining models we keep length of stay as control variable.

12 We have also tested these models including the squared value of length of stay to test for possible curvilinear effects which indeed are confirmed, i.e, the effect of length of stay on the probability of acquiring a party preference increases until a certain threshold is reached when the effect decreases. Given that curvilinear effects are not crucial to the main argument we have opted for the standard length of stay models (results not shown but available upon request). 
TABLE 2

LOGISTIC REGRESSION MODELS, IMMIGRANT'S POLITICAL INTEGRATION IN SPAIN

\begin{tabular}{|c|c|c|c|c|}
\hline & M1 & M2 & M3 & M4 \\
\hline \multirow[t]{2}{*}{ Gender ( $1=$ female $)$} & $-0.19^{\star *}$ & $-0.27^{\star \star \star}$ & $-0.23^{\star \star \star}$ & $-0.30^{\star \star \star}$ \\
\hline & $(0.09)$ & $(0.09)$ & $(0.09)$ & $(0.09)$ \\
\hline \multicolumn{5}{|l|}{ Age (ref: >55) } \\
\hline \multirow[t]{2}{*}{$18-34$} & $0.24^{\star}$ & $0.32^{\star *}$ & 0.23 & $0.29^{\star \star}$ \\
\hline & $(0.14)$ & $(0.14)$ & $(0.14)$ & $(0.14)$ \\
\hline \multirow[t]{2}{*}{$35-54$} & $0.34^{\star \star \star}$ & $0.42^{\star \star \star}$ & $0.34^{\star \star \star}$ & $0.41^{\star \star \star}$ \\
\hline & $(0.13)$ & $(0.13)$ & $(0.13)$ & $(0.13)$ \\
\hline \multirow[t]{2}{*}{ Education (1=University) } & $0.54^{\star \star \star}$ & $0.51^{\star \star \star}$ & $0.54^{\star \star \star}$ & $0.48^{\star \star \star}$ \\
\hline & $(0.11)$ & $(0.12)$ & $(0.12)$ & $(0.12)$ \\
\hline \multirow[t]{2}{*}{ Length of Stay in Spain } & $0.04^{\star \star \star}$ & $0.05^{\star \star \star}$ & $0.03^{\star \star \star}$ & $0.04^{\star \star \star}$ \\
\hline & $(0.01)$ & $(0.01)$ & $(0.01)$ & $(0.01)$ \\
\hline \multicolumn{5}{|l|}{$\begin{array}{l}\text { H1: Cultural proximity } \\
\text { (ref: non Latin-American) }\end{array}$} \\
\hline \multirow[t]{2}{*}{ Latin-Americans } & & $0.67^{\star \star \star}$ & & \\
\hline & & $(0.09)$ & & \\
\hline \multicolumn{5}{|l|}{$\begin{array}{l}\text { H2: Immigration Status } \\
\text { (ref: non naturalized) }\end{array}$} \\
\hline \multirow[t]{2}{*}{ Naturalized } & & & $0.93^{\star \star \star}$ & \\
\hline & & & $(0.11)$ & \\
\hline \multicolumn{5}{|c|}{$\begin{array}{l}\text { H3: Immigration Status \& Cultural Proximity combined } \\
\text { (ref: others-non naturalised) }\end{array}$} \\
\hline \multirow[t]{2}{*}{ European } & & & & $0.26^{\star \star}$ \\
\hline & & & & $(0.13)$ \\
\hline \multirow[t]{2}{*}{ Latin-American } & & & & $0.52^{\star \star \star}$ \\
\hline & & & & $(0.12)$ \\
\hline \multirow[t]{2}{*}{ Latin-American naturalised } & & & & $1.41^{\star \star \star}$ \\
\hline & & & & $(0.15)$ \\
\hline \multirow[t]{2}{*}{ Others-naturalised } & & & & $0.81^{\star \star \star}$ \\
\hline & & & & $(0.18)$ \\
\hline \multirow[t]{2}{*}{ Constant } & $-1.48^{\star \star \star}$ & $-1.80^{\star \star \star}$ & $-1.49^{\star \star \star}$ & $-1.80^{\star \star \star}$ \\
\hline & $(0.16)$ & $(0.17)$ & $(0.16)$ & $(0.18)$ \\
\hline Pseudo $\mathrm{R}^{2}$ & 0.0334 & 0.0508 & 0.0575 & 0.0683 \\
\hline Observations & 2,369 & 2,360 & 2,362 & 2,360 \\
\hline
\end{tabular}

Standard errors in parentheses

*** $p<0.01,{ }^{* \star} p<0.05,{ }^{*} p<0.1$ 
Nonetheless, our hypotheses are possibly best graphically tested to show the predictive margins for each of our independent variables (Figure 3 and 4) following the logistic regressions of Table 1. Figure 1 compares the effect of cultural proximity vs that of naturalization (for all migrants who have naturalized). At a first look one would jump to the conclusion that the effect of naturalization is stronger and therefore that naturalization can work to compensate, to some extent, the initial cultural advantage of Latin-Americans. However, we know that rules accessing citizenship in Spain are not neutral to the cultural attributes of migrants, so it might be that the apparent stronger effect of naturalization is actually a reflection on how the latter reinforces the initial cultural gap between different minorities.

In order to clarify this, Figure 4 shows the predictive margins from model 4 by cultural/immigration status groups, and reflects the following hierarchical group order in the probability of having a party preference, from bottom to top: non-naturalized other TCNs (0.26), EU citizens (0.32), non-naturalized Latin Americans (0.37), naturalized other TCNs (0.44), and naturalized Latin Americans. This hierarchy confirms the idea that security of residential status (EU citizens) is indeed better for political integration than the nonsecurity of other TCNs, but at the same time is not strong enough to compensate the initial advantage of the cultural advantage of Latin Americans. The results also confirm the idea that naturalization in both cultural groups clearly incentivise political engagement to the extent that the naturalized other TCNs leap-frog EU citizens in their political integration. Finally, following the selective hypothesis above, we expected that the more restrictive regime for other TCNs could actually have the effect of closing the gap between the two groups, given the harder rules applied to other TCNs. The results of the graph refute the selective hypothesis, since the gap between the two groups slightly widens after naturalization: 0.14 points vs 0.11 , which suggests, on the contrary, that easier rules to access citizenship promote more politically integrated migrants than harder rules, thus reinforcing the initial cultural gap, although moderately so. 
FIGURE 3

CULTURAL AND CITIZENSHIP HYPOTHESIS, MARGINS PLOT

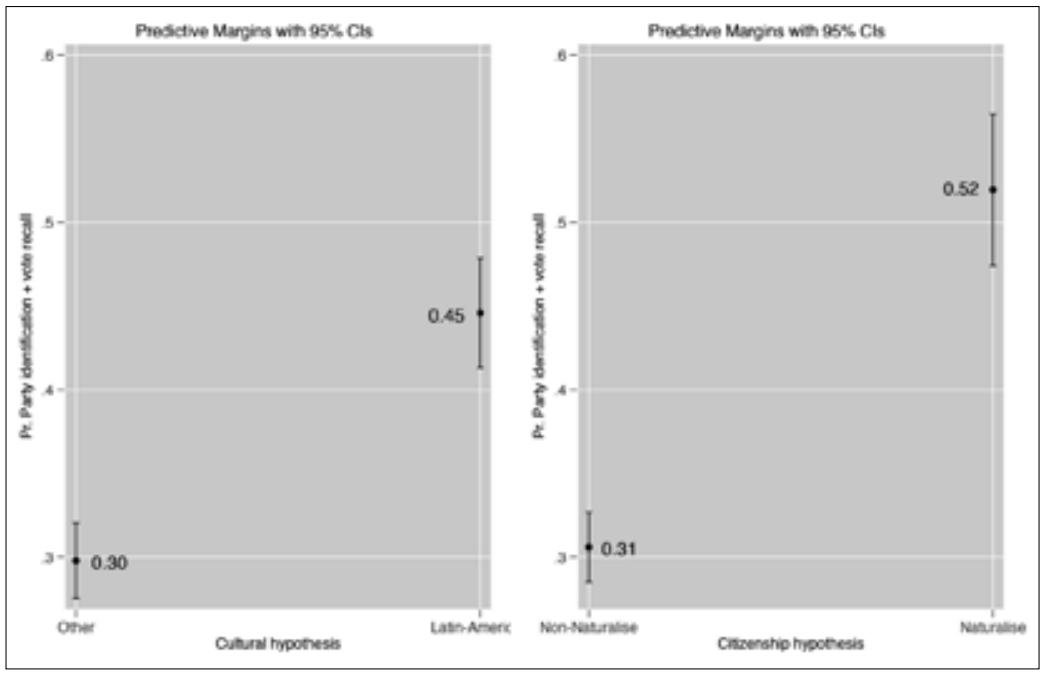

FIGURE 4

IMMIGRATION STATUS \& CULTURAL PROXIMITY COMBINED, MARGINS PLOT

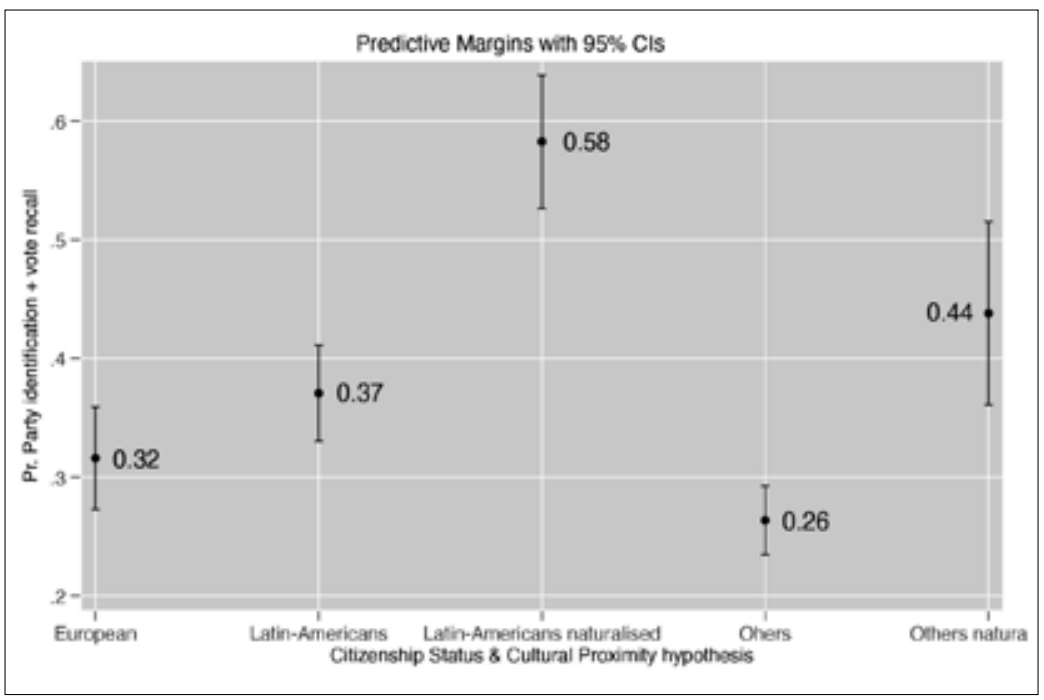




\section{CONCLUSION}

Our results show a clear combined effect of having Latin American origins and being naturalized on the acquisition of a party preference among immigrants in Spain. On the one hand, the greater cultural-linguistic closeness of Latin American immigrants to the predominant cultural-linguistic profile in Spain clearly favors their political integration. Our results signal that language works as a key factor to the political integration of immigrants, as it is in other aspects of their integration in the host country. This factor should not be overlooked, as failure to integrate can have cumulative disadvantages over the course of life. Additionally, the generation of a multi-ethnic public sphere (Lobera et al, 2017), with a larger presence of political information in other languages, would favor the political integration of immigrants.

With regard to the effects of immigration status, our results underline that naturalization is associated with a higher political integration in Spain, confirming previous studies that find this same relationship in other contexts. But there are also other interesting findings.

Although EU citizenship secures residential status for some minorities it might also become an (unintended) obstacle that discourages the political integration of EU migrant minorities in the medium-long term (which does not seem to be compensated by the voting rights at the local level associated to EU status). Our research also suggests that the political integration of migrants might be best secured with easier (rather than harder) rules to access citizenship.

Finally, our findings send a moderate warning against the policy of applying different rules of access to citizenship that can aggravate the gap (in terms of integration) between different migrant minorities. Additionally, our research also calls for some reflection with regard to naturalization policy. In its latest report for 2020 MIPEX gives Spain a score of 30 in its policy of access to nationality, well below the average of all countries examined; and - when compared to rest of EU Member states- only ahead of some Eastern European countries and Austria; and far below the best evaluated EU country in this domain, Portugal (86) which in 2006 implemented a reform to equalize access to nationality across different migrant groups. 


\section{REFERENCES}

Adamson, G. (2007). Immigrants and political participation-Background, theory, and empirical suggestions. Wien: Fundamental Rights Agency.

Barreto, M., \& Muñoz, J. (2003). "Re-examining the 'politics of in-between': Political participation among Mexican immigrants in the United States", Hispanic Journal of Behavioral Sciences, 25(4), 427-447. https://doi. org/10.1177/0739986303258599

Bennett, L. L., \& Bennett, S.E. (1989). 'Enduring gender differences in political behavior', American Politics Research, 17, 105-22. https://doi. org/10.1177/1532673X8901700106

Bloemraad, I. (2017). Does Citizenship Matter? In A. Shachar, R. Bauböck, I. Bloemraad, \& M. Vink (Eds.), The Oxford Handbook of Citizenship (pp. 524-550). Oxford: Oxford University Press.

Calvo Buezas, T. (2019). Voces de inmigrantes. Madrid: Observatorio Español del Racismo y la Xenofobia.

Campbell, A. (1960). Surge and decline: A study of electoral change. Public opinion quarterly, 24(3), 397-418. https://doi.org/10.1086/266960

Cho, W. (1999). Naturalization, Socialization, Participation: Immigrants and (Non-) Voting. Journal of Politics, 61(4), 1140-1155, November, Cambridge University Press on behalf of the Southern Political Science Association.

Connor, P., \& Massey, D. S. (2010). Economic Outcomes among Latino Migrants to Spain and the United States: Differences by Source Region and Legal Status. The International migration review, 44(4), 802-829. https://doi.org/10.1111/j.1747-7379.2010.00826.x, page 2 .

Dalton, R. J., y Wattenberg, M. P. (2002). Parties without partisans: Political change in advanced industrial democracies, Oxford: Oxford University Press.

Dassonneville, R. (2013). “Questioning generational replacement. An age, period and cohort analysis of electoral volatility in the Netherlands, 1971-2010". Electoral Studies, 32(1), 7-47. https://doi.org/10.1016/j. electstud.2012.09.004.

De Roiij, E. A. (2012). Patterns of Immigrant Political Participation: Explaining Differences in Types of Political Participation between Immigrants and the Majority Population in Western Europe. European Sociological Review, 18(4), 455-481. https://doi.org/10.1093/esr/jcr010

DeSipio, L. (1996). Counting on the Latino Vote: Latinos as a New Electorate. Charlottesville: The University Press of Virginia.

Duncan, N. T., \& Waldorf, B. S. (2009). Becoming a US citizen: the role of immigrant enclaves. Cityscape, 11(3), 5-28. http://dx.doi.org/10.2139/ ssrn. 1583147

Donovan, B. (2007). 'Minority' representation in Germany. German Politics, 16(4), 455-480. https://doi.org/10.1080/09644000701652482 
Finotelli, C., \& La Barbera, M.C. (2013). When the exception becomes the rule: the Spanish Citizenship Regime. Migration Letters, 10 (2), 245-253. https://doi.org/10.33182/ml.v10i2.146

Giménez, C., Lobera, J., \& Parejo, D. (2018). Convivencia sociale intercultural en territorios de alta diversidad. Encuesta 2017. Barcelona: Obra Social "la Caixa".

González Ferrer, A. (2011). The electoral participation of naturalized immigrants in ten Eropean Cities. In Morales, L. \& Giugni, M. (Eds.), Social capital, political participation and migration in Europe (pp. 63-87). Basingstoke: Palgrave Macmillan.

Gustafson, P., \& Cardozo, A. E. L. (2017). Language Use and Social Inclusion in International Retirement Migration. Social Inclusion, 5(4), 69-77. https://doi.org/10.17645/si.v5i4.1133

Graeber, J. (2016). Citizenship in the shadow of the Euro crisis: explaining changing patterns in naturalisation among intra-EU migrants. Journal of Ethnic and Migration Studies, 42(10), 1670-1692. https://doi.org/10.1080 /1369183X.2016.1162353

Hainmueller, J., Hangartner, D., \& Pietrantuono, G. (2015). Naturalization fosters the long-term political integration of immigrants. Proceedings of the National Academy of Sciences, 112(41), 12651-12656. doi:10.1073/ pnas.1418794112

Heizmann, B., \& Boehnke, P. (2016). Migrant poverty and social capital: The impact of intra- and interethnic contacts. Research in Social Stratification and Mobility, 46(B), 73-85. https://doi.org/10.1016/j.rssm.2016.08.006

Huddleston, T., \& Tajden, JD. (2012). Cómo perciben los inmigrantes la integración en 15 ciudades europeas. Barcelona: CIDOB.

Huddleston, T., Bilgili, Ö., Joki, A. L., \& Vankova, Z. (2015). Migrant integration policy index 2015. Barcelona/Brussels: CIDOB and MPG.

Joppke, C. (2005). Selecting by Origin: Ethnic Migration in the Liberal State. Cambridge, MA: Harvard University Press.

Joppke, C. (2010). The Inevitable Lightening of Citizenship. European Journal of Sociology, 51(1), pp. 9-32. https://doi.org/10.1017/S0003975610000019

Kam, C. D., \& Ortiz, A M. (1998). Who's asking whom? Race, recruitment and political participation. Paper Presented at the 1998 Annual Meeting of the American Political Science Association, Boston, September 3-6.

Koopmans, R. et al. (2005). Contested citizenship: Immigration and cultural diversity in Europe. Vol. 25. Minneapolis: University of Minnesota Press.

Lasala-Blanco, N., Morales, L., y Pamies, C. (2021). Forging Political Identities and Becoming Citizens: The Political Preferences and Engagement of South American Immigrants in the United States and Spain. American Behavioral Scientist, in press. https://doi.org/10.1177/0002764221996752

Lobera, J., Arco, V., \& Giménez, C. (2017). Toward a multi-ethnic public sphere? Media consumption in highly diverse districts in Spain. International Migration, 55(2), 39-52. https://doi.org/10.1111/imig.12278 
Lobera, J. (2021). Postcolonial Bonds? Latin American Origins, Discrimination, and Sense of Belonging to Spain. American Behavioral Scientist, in press. https://doi.org/10.1177/0002764221996757.

Morales, L., \& Giugni, M. (2011). Social capital, political participation and migration in Europe. Basingstoke: Palgrave Macmillan.

Martínez de Lizarrondo, A. (2016). Naturalizaciones en España: Indicador de integración y estrategia frente a la crisis. Migraciones, (39), 3-37. https://doi.org/10.14422/mig.i39y2016.001

McAreavey, R. (2017). New immigration destinations: Migrating to rural and peripheral areas. London: Routledge.

Nam, Y., \& Kim, W. (2012). Welfare reform and elderly immigrants' naturalization: Access to public benefits as an incentive for naturalization in the United States. International Migration Review, 46(3), 656-679. https://doi.org/10.1111/j.1747-7379.2012.00900.x

Pamies, C., Pérez-Nievas, S, Vintila, D., y Paradés, M. (2021). Descriptive Political Representation of Latin Americans in Spanish Local Politics: Demographic Concentration, Political Opportunities, and Parties' Inclusiveness. American Behavioral Scientist, in press. https://doi.org/10.1177/0002764221996755

Pérez-Nievas, S., Vintila, D., Morales, L. y \& Paradés, M. (2014). La representación política de los inmigrantes en España: un análisis empírico. Madrid: Centro de Investigaciones Sociológicas.

Peters, F., Schmeets, H., \& Vink, M. (2019). Naturalisation and Immigrant Earnings: Why and to Whom Citizenship Matters. European Journal of Population, (36), 511-545. https://doi.org/10.1007/s10680-019-09540-1

Portes, A., Fernández-Kelly, P., \& Haller, W. (2009). The adaptation of the immigrant second generation in America: A theoretical overview and recent evidence. Journal of ethnic and migration studies, 35(7), 10771104. https://doi.org/10.1080/13691830903006127

Portes, A., Celaya, A., Vickstrom, E., \& Aparicio, R. (2012). Who are we? Parental influences on self-identities and self-esteem of second generation youths in Spain. RIS, 70(1), 9-37. 10.3989/ris.2011.09.26

Rissing, B. A., \& Castilla, E. J. (2014). House of green cards: Statistical or preference-based inequality in the employment of foreign nationals. American Sociological Review, 79(6), 1226-1255. https://doi. org $/ 10.1177 / 0003122414553656$

Schönwälder, K. (2013). Immigrant representation in Germany's regional states: The puzzle of uneven dynamics. West European Politics, 36(3), 634-651. https://doi.org/10.1080/01402382.2013.773730

Soto, V.M. \& Merolla, J. (2006). 'Vota por tu Futuro: Partisan Mobilization of Latino Voters in the 2000 Presidential Election'. Political Behaviour, 28, 285-304. https://doi.org/10.1007/s11109-006-9012-7

Thomassen, J. J. A., \& Rosema, M. (2009). Party identification revisited. In J. Bartle \& P. Belluci (Eds.), Political Parties and Partisanship. Social Identity and Individual Attitudes (42-95). London: Routledge. 
Uhlaner, C. J., \& Garcia, F. C. (2005). Learning which party fits: Experience, ethnic identity, and the demographic foundations of Latino party identification. In B. Norrander \& C. Wilcox (Eds.) Diversity in democracy: Minority representation in the United States (72-101), Washington DC: CQ Press.

Vink, M. P., Prokic-Breuer, T., and Dronkers, J. (2013). Immigrant naturalization in the context of institutional diversity: policy matters, but to whom? International Migration, 51(5), 1-20. https://doi.org/10.1111/ imig. 12106

Wong, J. S. (2000). The effects of age and political exposure on the development of party identification among Asian American and Latino immigrants in the United States. Political Behavior, 22(4), 341-371. https://doi.org/10.1023/A:1010630130895 
